\begin{tabular}{|c|c|}
\hline Title & The rare earth element (REE) lanthanum ( $L a)$ induces hormesis in plants \\
\hline Author(s) & A gathokleous, Evgenios; Kitao, Mitsutoshi; Calabrese, Edward J. \\
\hline Citation & $\begin{array}{l}\text { Environmental pollution, 238, } 1044-1047 \\
\text { https://doi.org/10.1016/.envpol.2018.02.068 }\end{array}$ \\
\hline Issue Date & $2018-07$ \\
\hline Doc URL & http:/hdl.handle.net/2115/78853 \\
\hline Rights & $\begin{array}{l}\text { (0) } 2018 \text { Elsevier Ltd. All rights reserved., @ 2018. This manuscript version is made available under the CC-BY-NC-ND } \\
4.0 \text { license http://treativecommons.org/icenses/by-nc-nd/4.0/ }\end{array}$ \\
\hline Rights(URL) & http://creativecommons.org/icenses/by-nc-nd/4.0/ \\
\hline Type & article (author version) \\
\hline File Information & Manuscript2-1.pdf \\
\hline
\end{tabular}

Instructions for use 


\section{The rare earth element (REE) lanthanum (La) induces hormesis in plants}

Evgenios Agathokleous ${ }^{1,2^{*}}$, Mitsutoshi Kitao ${ }^{1}$, Edward J. Calabrese ${ }^{3}$

${ }^{1}$ Hokkaido Research Center, Forestry and Forest Products Research Institute (FFPRI), Forest Research and

Management Organization, 7 Hitsujigaoka, Sapporo, Hokkaido, 062-8516, Japan.

${ }^{2}$ Research Faculty of Agriculture, School of Agriculture, Hokkaido University, Kita 9 Nishi 9, Sapporo, Hokkaido, 060-8589, Japan.

${ }^{9}$ Department of Public Health, Environmental Health Sciences, Morrill I, N344, University of Massachusetts, Amherst, MA 01003, USA.

*Corresponding author: Tel: +81-11-851-4131, Fax: +81-11-851-4167, Email: globalscience@frontier.hokudai.ac.jp or evgenios@affrc.go.jp

Abstract: Lanthanum is a rare earth element (REE) which has been extensively studied due to its wide application in numerous fields with a potential accumulation in the environment. It has long been known for its potential to stimulate plant growth within a hormetic-biphasic dose response framework. This article provides evidence from a series of high resolution studies published within the last two decades demonstrating a substantial and significant occurrence of lanthanum-induced hormesis in plants. These findings suggest that hormetic responses should be built into the study design of hazard assessment study protocols and included in the risk assessment process. Hormesis also offers the opportunity to substantially improve cost benefit estimates for environmental contaminants, which have the potential to induce beneficial/desirable effects at low doses.

Keywords: dose-response; hormesis; lanthanum; risk assessment; U-shape curve

Capsule: The response of plants to lanthanum is often described by hormetic model 


\section{INTRODUCTION}

Lanthanum $^{1}$ (La) is the lanthanide with the largest atomic radius. Fifteen lanthanides, scandium (Sc), and yttrium (Y) are chemicals elements of the periodic table which have been defined by IUPAC as rare earth elements (REEs). Despite their name, these elements are not particularly rare and can be found in well measurable concentrations in the crust of Earth. REEs do not occur naturally at high concentrations in the environment but may occur at high concentrations due to their utilization by and application within a wide spectrum of fields, including agriculture, industry and medicine (García-Jiménez et al., 2017; Hu et al., 2016; Lin et al., 2017; von Tucher and Schmidhalter, 2005).

Dose responses represent the backbone of toxicology and are necessary for assessing the effects of pollutants. Dose response relationships are established for assessing risks and deriving critical levels below which chemicals or pollutants do not pose a threat for adverse effects. Throughout the $20^{\text {th }}$ century, the prevailing belief was that the response of biological organisms to chemical or environmental stressors increases linearly with increasing dose (linear-no-threshold model) or remains neutral up to a certain threshold and then increases linearly with increasing dose (threshold model) (Fig 1).

Hormesis is a biphasic dose response characterized by stimulation at low doses and inhibition at high doses (Fig 1). While hormesis has a long history (Calabrese and Baldwin., 1999; Stebbing, 1982), especially in the area of plant biology (Calabrese and Baldwin, 2000; Calabrese and Blain, 2009), it has taken on renewed focus over the past several decades (Abbas et al., 2017; Agathokleous, 2017; Belz and Piepho, 2017; Calabrese and Blain, 2011, 2009, Cedergreen et al., 2009, 2007; Agathokleous, 2018; Poschenrieder et al., 2013; VargasHernandez et al., 2017). A recent paper published in Environmental Pollution reports the results from an experiment where the effects of La pollution are assessed in soybean seedlings under different acid rain scenarios (Zhang et al., 2017). Although this study focused

\footnotetext{
1 From the ancient Greek word $\lambda \alpha \nu \theta \alpha$ óvıı (lanthanein), meaning "stay unnoticed” or "escape attention”
} 
on the mechanisms underlying plant response, thanks to its robust experimental design, the results show hormesis induced by the earth lanthanum ion $\left(\mathrm{La}^{3+}\right)$ and call for re-examination of published literature dealing with the effects of La on plants.

\section{ANALYSIS}

Based on a re-examination of published literature, collective evidence for significant La-induced hormetic responses is shown for 9 species and at least 4 cultivars/varieties in 20 studies published in 12 journals over the period 2001-2017; 13 of them (65\%) were published in the period 2012-2017.

\section{Hormesis in a variety of species}

Taxus yunnanensis cell cultures exposed to $\mathrm{La}^{3+}(\leq 46.2 \mu \mathrm{M}, 28 \mathrm{~d})$ displayed a hormetic response (MAX at $5.8 \mu \mathrm{M}$ ) in average cell growth rate (Fig 2A) and taxol production (Wu et al., 2001). Desert broomrape cell cultures (Cistanche deserticola Ma) exposed to $\mathrm{La}^{3+}\left(\leq 0.1 \mathrm{mmol} \mathrm{L}{ }^{-1}, 30 \mathrm{~d}\right)$ showed hormetic response (MAX at $0.01 \mathrm{mmol} \mathrm{L}^{-1}$ ) in dry weight (Fig 2B) and phenylethanoid glycosides content and production (Ouyang et al., 2003). Similarly, bush bean (Phaseolus vulgaris L.) treated with $\mathrm{LaCl}_{3} \leq 72 \mu \mathrm{mol} \mathrm{Kg}{ }^{-1}$ and spinach (Spinacea oleracea L.) treated with $\mathrm{LaCl}_{3} \leq 360 \mu \mathrm{mol} \mathrm{Kg}{ }^{-1}$ for more than a month showed MAX at $3.6 \mu \mathrm{mol} \mathrm{Kg}{ }^{-1}$ (bean $110 \%$, spinach 135\%), however non-significant for bean (von Tucher and Schmidhalter, 2005). Durum wheat (Triticum durum Desf.) treated with $\mathrm{La}^{3+}$ ( $\leq 10 \mathrm{mM}, 9 \mathrm{~d}$ ) showed hormesis in root length with MAX at $0.01 \mathrm{mM}$ (Fig 2C), although the stimulation at 0.01 and $0.1 \mathrm{mM}$ did not appear at 6 and 12 days (d'Aquino et al., 2009). Horseradish (Armoracia rusticana G.Gaertn.) had greater (114\%) and lower (69\%) average cell size of fourth true leaf 6 days after treatment (DAT) with 30 or $80 \mu \mathrm{M} \mathrm{LaCl} 3$ compared with $0 \mu \mathrm{M} \mathrm{LaCl}_{3}$ (Wang et al., 2014a).When horseradish was exposed to 13 doses ranging between 0 and $200 \mathrm{LaCl}_{3}$ in a field experiment conducted annually for five years, hormetic dose-response relationship appeared in yield (Fig $2 D)$, net photosynthetic rate $\left(P_{N}\right)$, chlorophyll content and peroxidase activity, with MAX at $35 \mu \mathrm{M}$ (Wang et al., 2014a); 

showed significant stimulation in wet weight by $50 \mathrm{mg}$ La chloride heptahydrate $\left(\mathrm{LaCl}_{3}\right.$ $7 \mathrm{H}_{2} \mathrm{O}$ ) in contrast to significant inhibition by 100,200 and $400 \mathrm{mg} \mathrm{LaCl}_{3} 7 \mathrm{H}_{2} \mathrm{O}$, three weeks after the treatments application (Turra et al., 2015).

\section{Hormesis in rice}

Hormesis was found multiple times in rice (Oryza sativa L.). Seedlings grown in red soil and exposed to $\mathrm{LaCl}_{3}\left(\leq 1200 \mathrm{mg} \mathrm{Kg}{ }^{-1}\right)$ displayed hormesis with MAX at $30 \mathrm{mg} \mathrm{Kg}^{-1}$ in plant height and tillers (Fig 2E) at 30 DAT, but not at 80 DAT, however MAX was nonsignificant for tillers (Zeng et al., 2006). In other studies, hormesis was found in fresh root weight (Fig $2 F$ ), length of total nodal root, number of nodal roots and number of total lateral roots of nodal roots (Liu et al., 2013), and in soluble protein content and activity of peroxidase (Fig 2G) and catalase in the roots (Liu et al., 2016) of seedlings exposed to $\mathrm{La}^{3+}$

$(\leq 1.5 \mathrm{mM}, 13 \mathrm{~d})$ with MAX at 0.05 or $0.1 \mathrm{mmol} \mathrm{L}^{-1}$. When exposed to $0,81.6,1224.5$ and $2449 \mu \mathrm{M} \mathrm{LaCl}$, rice displayed hormesis in $P_{\mathrm{N}}$, stomatal conductance, Hill reaction rate, apparent quantum yield (AQY) and carboxylation efficiency (CE) at different growth stages and at different $\mathrm{pH}$; stimulation occurred only at $81.6 \mu \mathrm{M}$ (Wang et al., 2014b). Hormesis appeared in the content of $\mathrm{Mg}, \mathrm{P}, \mathrm{K}, \mathrm{Ca}, \mathrm{Mn}, \mathrm{Fe}$ and $\mathrm{Ni}$, transcription of several chloroplast ATPase subunit genes, activity of Mg2+ -ATPase, $P_{\mathrm{n}}$, dry and fresh weight of leaves, leaf area and relative growth rate in rice exposed to $0,0.08,1.2$, and $2.4 \mathrm{mM} \mathrm{La}\left(\mathrm{LaCl}_{3}{ }_{6} \mathrm{H}_{2} \mathrm{O}\right)$ for 15 d; MAX commonly occurred at $0.08 \mathrm{mM}$ (Hu et al., 2016).

\section{$97 \quad$ Hormesis in soybean}

98 Hormesis was also frequently found in soybean (Glycine max L.). Seedlings treated 99 with $\mathrm{La}^{3+}(\leq 1.2 \mathrm{mM}, 7 \mathrm{~d})$ and simulated acid rain with $\mathrm{pH}$ 7.0, 4.5 or 3.5 showed hormesis in chlorophyll content and main root length at all pH levels; in plant height, leaf area,

101 photochemical yield of photosystem II ( $\left.\Phi_{\text {PSII }}\right)$ and Hill reaction rate (Fig $\left.2 H\right)$ only at pH 7.0;

102 in initial fluorescence $\left(F_{0}\right)$, dry weight of leaves and stem and dry weight of root at $\mathrm{pH} 7.0$ 
and 4.5; and in $P_{\mathrm{n}}$ at $\mathrm{pH} 7.0$ and 3.5 (Wen et al., 2011). In the same experimental design, hormesis was found in $\mathrm{Mg}$ at $\mathrm{pH}$ 4.5; in nitrate reductase transcriptional level at $\mathrm{pH} 7.0$ (Fig 2I); in $\mathrm{K}$ and Fe content at $\mathrm{pH} 7.0$ and 4.5; and in nitrate reductase activity at all pH levels (Xia et al., 2017). Under the same conditions, hormesis was found in multiple root endpoints: amino acid content at $\mathrm{pH}$ 7.0; glutamine synthetase activity at $\mathrm{pH} 7.0$ and 4.5 ; $\mathrm{NO}^{-3}$ content at pH 7.0 and 3.5; glutamate dehydrogenase (DGH) activity at $\mathrm{pH} 4.5$ and 3.5; nitrate reductase activity and $\mathrm{NH}^{+4}$ content; and glutamine-oxoglutarate amino transferase (GOGAT) activity (Fig $2 J$ ) and soluble protein content at all pH levels (Zhang et al., 2017). In the latter three studies stimulation occurred at $0.08 \mathrm{mM}$. Hormesis was also found in $P_{\mathrm{N}}$ (Fig $2 \mathrm{~K}$ ), content of

$112 \mathrm{Cu}$ in roots, and content of $\mathrm{Cu}, \mathrm{Fe}$ and $\mathrm{Zn}$ in shoots of seedlings treated with $\mathrm{La}\left(\mathrm{NO}_{3}\right)_{3} 6 \mathrm{H}_{2} \mathrm{O}$

113 (160 $\mu \mathrm{M}, 28 \mathrm{~d}$ ), with significant stimulation at 5 and/or $10 \mu \mathrm{M}$ (de Oliveira et al., 2015).

\section{Hormesis in broad bean}

115 Finally, several hormetic dose responses were found in and claimed for broad bean

116 (Vicia faba L.) too. Clear $U$-shape dose-responses were found in guaiacol peroxidase (GPX)

117 activity, heat shock protein 70 (HSP 70) level and endoprotease isozymes (Fig $2 L$ ) in roots of 118 seedlings exposed to $\mathrm{La}\left(\mathrm{NO}_{3}\right)_{3}(0-12 \mathrm{mg} / \mathrm{L}=10.2-433 \mu \mathrm{g} \mathrm{La} / \mathrm{g}$ root dry weight, $15 \mathrm{~d})$ with

119 MAX at 0.5 or $1 \mathrm{mg} / \mathrm{L}$ (=74.9 or $108 \mu \mathrm{g} / \mathrm{g}$ ) ,although with high variance (Wang et al., 2011).

120 In a further study, seedlings hydroponically cultured under $6 \mu \mathrm{mol}$ cadmium chloride $\left(\mathrm{CdCl}_{2}\right)$

$121 \mathrm{~L}^{-1}$ and a range of $\mathrm{La}\left(\mathrm{NO}_{3}\right)_{3}$ levels $(0-480 \mathrm{mg} / \mathrm{L}, 15 \mathrm{~d})$ showed hormesis in Cd content, 122 superoxide dismutase (SOD) activity, GPX activity, catalase activity, ascorbate peroxidase 123 (APX) isozyme activity and HSP 70 production (Fig 2M) in the roots; stimulation occurred between 2 and 120 for all endpoints and was significant for all endpoints except APX activity 125 (Wang et al., 2012a). Under the same experimental conditions, leaf $\mathrm{K}$ and Mo content and 126 APX activity (Fig 2N) showed clear hormetic responses with significant effects in the low 127 dose region being observed in the range 8-120 mg/L; catalase activity also showed U-shaped 128 dose response but with no any significant effects (Wang et al., 2012c). Root HSP 70 
129 production showed also a $U$-shaped dose-response (Fig 2O) when seedlings were exposed to

1309 doses of $\mathrm{La}\left(\mathrm{NO}_{3}\right)_{3}\left(0-16 \mathrm{mg} \mathrm{L}^{-1}, 10 \mathrm{~d}\right)$, with MAX at $0.5 \mathrm{mg} \mathrm{L}^{-1}$ albeit non-statistically

131 significant (Wang et al., 2012b). In a different study, seedlings exposed to 5 low doses of

$132 \mathrm{La}\left(\mathrm{NO}_{3}\right)_{3}\left(0-8 \mathrm{mg} \mathrm{L}^{-1}, 20 \mathrm{~d}\right)$, showed significant effects, only at 2 or $4 \mathrm{mg} \mathrm{L}^{-1}$, that would

133 contrast the expected effects by high doses in root $\mathrm{Cu}$ content, tail length of root tips (Fig 2P)

134 and apical leaves nuclei, and tail moment of root tips and apical leaves nuclei (Wang et al., 135 2012d).

136

137

138

139

\section{CONCLUSIONS}

This study provides evidence from a series of recent papers showing that hormesis commonly occurs in a variety of plants in response to La. These findings build upon a strong historical research foundation demonstrating La-induced hormesis in plants during the last three decades of the $20^{\text {th }}$ century (Hu et al., 2004).

The effects at low La doses may be driven by micro-interference to the molecular structure of vitronectin-like protein (VN), whereas the effects of high La doses may be upon binding to VN with a formation of stable La-VN complexes that leads to damage in the VN molecular structure (Wang et al., 2017).

The collective evidence presented here challenges the research community to assess the nature of the dose response over the full dose-response continuum and with appropriate dose spacing especially in the low dose zone. It also suggests the need to investigate whether a prior exposure to low doses of La, which induce biological stimulation, can protect against a subsequent exposure to higher doses of La, so called preconditioning (Calabrese, 2016a, 2016b).

La-induced hormesis in plants, as well as the broader hormetic literature, indicate that hormesis should be incorporated within the hazard and risk assessment process for deriving environmental quality standards. REEs, including La, can be utilized in agricultural practice 
154 (Ozaki et al., 2000; Tommasi and D’Aquino, 2017; Xu et al., 2002; Zhang et al., 2015), and, 155 thus, hormesis should be incorporated into the agricultural practice as well for the optimum 156 beneficial effects within an optimized cost benefit framework.

157 Acknowledgements: The authors of the original articles are acknowledged for the 158 fundamental contribution in developing this understanding. EA is an International Research 159 Fellow (ID No: P17102) of the Japan Society for the Promotion of Science (JSPS). This 160 research was supported by JSPS KAKENHI Grant Number JP17F17102 (EA and MK). JSPS

161 is a non-profit, independent administrative institution. EJC acknowledges longtime support 162 from the US Air Force (AFOSR FA9550-13-1-0047) and ExxonMobil Foundation 163 (S18200000000256). The U.S. Government is authorized to reproduce and distribute for 164 governmental purposes notwithstanding any copyright notation thereon. The views and 165 conclusions contained herein are those of the author and should not be interpreted as 166 necessarily representing policies or endorsement, either expressed or implied. Sponsors had 167 no involvement in study design, collection, analysis, interpretation, writing and decision to 168 and where to submit for publication consideration.

\section{REFERENCES}

170 Abbas, T., Nadeem, M.A., Tanveer, A., Chauhan, B.S., 2017. Can hormesis of plant-released 171 phytotoxins be used to boost and sustain crop production? Crop Protect. 93, 69-76.

172 Agathokleous, E, 2018. Environmental hormesis, a fundamental non-monotonic biological 173 phenomenon with implications in ecotoxicology and environmental safety. Ecotox. Environ. 174 Safe. 148, 1042-1053.

175 Agathokleous, E., 2017. Perspectives for elucidating the ethylenediurea (EDU) mode of 176 action for protection against $\mathrm{O}_{3}$ phytotoxicity. Ecotox. Environ. Safe. 142, 530-537.

177 Belz, R.G., Piepho, H.-P., 2017. Predicting biphasic responses in binary mixtures: Pelargonic 
acid versus glyphosate. Chemosphere 178, 88-98.

179 Calabrese, E.J., 2016a. Preconditioning is hormesis part II: How the conditioning dose mediates protection: Dose optimization within temporal and mechanistic frameworks. Pharm.

181 Res. 110, 265-275.

182 Calabrese, E.J., 2016b. Preconditioning is hormesis part I: Documentation, dose-response 183 features and mechanistic foundations. Pharm. Res. 110, 242-264.

184 Calabrese, E.J., Baldwin., L.A., 1999. Chemical hormesis: Its historical foundations as a 185 biological hypothesis. Toxicol. Pathol. 27, 195-216.

186 Calabrese, E.J., Baldwin, L.A., 2000. Radiation hormesis: its historical foundations as a 187 biological hypothesis. Hum. Exp. Toxicol. 19, 41-75.

188 Calabrese, E.J., Blain, R.B., 2011. The hormesis database: The occurrence of hormetic dose 189 responses in the toxicological literature. Regul. Toxicol. Pharmacol. 61, 73-81.

190 Calabrese, E.J., Blain, R.B., 2009. Hormesis and plant biology. Environ. Pollut. 157, 42-48.

191 Cedergreen, N., Felby, C., Porter, J.R., Streibig, J.C., 2009. Chemical stress can increase crop 192 yield. Field Crop. Res. 114, 54-57.

193 Cedergreen, N., Streibig, J.C., Kudsk, P., Mathiassen, S.K., Duke, S.O., 2007. The 194 occurrence of hormesis in plants and algae. Dose-Response 5, 150-62. d’Aquino, L., de Pinto, M.C., Nardi, L., Morgana, M., Tommasi, F., 2009. Effect of some light rare earth elements on seed germination, seedling growth and antioxidant metabolism in

197 Triticum durum. Chemosphere 75, 900-905.

198 de Oliveira, C., Ramos, S.J., Siqueira, J.O., Faquin, V., de Castro, E.M., Amaral, D.C., 199 Techio, V.H., Coelho, L.C., e Silva, P.H.P., Schnug, E., Guilherme, L.R.G., 2015.

200 Bioaccumulation and effects of lanthanum on growth and mitotic index in soybean plants.

201 Ecotox. Environ. Safe. 122, 136-144.

202 García-Jiménez, A., Gómez-Merino, F.C., Tejeda-Sartorius, O., Trejo-Téllez, L.I., 2017. 
Lanthanum affects bell pepper seedling quality depending on the genotype and time of exposure by differentially modifying plant height, stem diameter and concentrations of chlorophylls, sugars, amino acids, and proteins. Front. Plant Sci. 8, 308. lanthanum (III) induced damage to plant photosynthesis. Ecotox. Environ. Safe. 127, 43-50. Hu, Z., Richter, H., Sparovek, G., Schnug, E., 2004. Physiological and biochemical effects of rare earth elements on plants and their agricultural significance: A review. J. Plant Nutr. 27, $183-220$.

Lin, R., Howard, B.H., Roth, E.A., Bank, T.L., Granite, E.J., Soong, Y., 2017. Enrichment of rare earth elements from coal and coal by-products by physical separations. Fuel 200, 506213520.

214 Liu, D., Wang, X., Zhang, X., Gao, Z., 2013. Effects of lanthanum on growth and accumulation in roots of rice seedlings. Plant Soil Environ. 59, 196-200. Liu, D., Zheng, S., Wang, X., 2016. Lanthanum regulates the reactive oxygen species in the 217 roots of rice seedlings. Sci. Rep. 6, 31860.

218 Ouyang, J., Wang, X., Zhao, B., Yuan, X., Wang, Y., 2003. Effects of rare earth elements on the growth of Cistanche deserticola cells and the production of phenylethanoid glycosides. J. Biotech. 102, 129-34.

221 Ozaki, T., Enomoto, S., Minai, Y., Ambe, S., Ambe, F., Mikide, Y., 2000. Beneficial effect 222 of rare earth elements on the growth of Dryopteris erythrosora, J. Plant Physiol., 156, 330223334.

224 Poschenrieder, C., Cabot, C., Martos, S., Gallego, B., Barceló, J., 2013. Do toxic ions induce 225 hormesis in plants? Plant Sci. 212, 15-25.

226 Stebbing, A.R.D., 1982. Hormesis - The stimulation of growth by low levels of inhibitors. 227 Sci. Total Environ. 22, 213-234. 
Tommasi, F., d’Aquino, L. 2017. Rare Earth Elements and Plants. In: Pagano, G. (Ed.) Rare

Earth Elements in Human and Environmental Health: At the Crossroads between Toxicity and Safety. pp. 107-126. Pan Stanford. ISBN 978-981-4745-00-0 (Hardcover). de J., Rico-Garcia, E., Ocampo-Velazquez, R. V., Alvarez-Arquieta, L. de L., Torres-Pacheco, I., 2017. Plant hormesis management with biostimulants of biotic origin in agriculture. Front. Plant Sci. 8, 1762.

von Tucher, S., Schmidhalter, U., 2005. Lanthanum uptake from soil and nutrient solution and its effects on plant growth. J. Plant Nutr. Soil Sci. 168, 574-580.

Wang, C., He, M., Shi, W., Wong, J., Cheng, T., Wang, X., Hu, L., Chen, F., 2011.

Toxicological effects involved in risk assessment of rare earth lanthanum on roots of Vicia faba L. seedlings. J. Environ. Sci. 23, 1721-1728. effects of lanthanum on Vicia faba L. seedlings under cadmium stress, implicating finite antioxidation and potential ecological risk. Chemosphere 86, 530-537.

Wang, C., Shi, C., Liu, L., Wang, C., Qiao, W., Gu, Z., Wang, X., 2012b. Lanthanum element induced imbalance of mineral nutrients, HSP 70 production and DNA-protein crosslink, leading to hormetic response of cell cycle progression in root tips of Vicia faba L. seedlings. Dose-Response 10, 96-107.

248 Wang, C., Xiao, J.-J., Tian, Y., Bao, X., Liu, L., Yu, Y., Wang, X.-R., Chen, T.-Y., 2012c.

249 Antioxidant and prooxidant effects of lanthanum ions on Vicia faba L. seedlings under cadmium stress, suggesting ecological risk. Environ. Toxicol. Chem. 31, 1355-1362. imbalance, DNA lesion and DNA-protein crosslink involved in growth retardation of Vicia 
faba L. seedlings exposed to lanthanum ions. J. Environ. Sci. 24, 214-220.

Wang, L., He, J., Yang, Q., Li, X., Wei, H., Chen, D.D.Y., Huang, X., 2017. A preliminary

255

256

257

258

259

260

261

262

263

264

265

266

267

268

269

270

271

272

273

274

275

276

277 study on the effects of lanthanum (III) on plant vitronectin-like protein and its toxicological basis. Ecotox. Environ. Safe. 145, 227-234.

Wang, L., Li, J., Zhou, Q., Yang, G., Ding, X.L., Li, X., Cai, C.X., Zhang, Z., Wei, H.Y., Lu, T.H., Deng, X.W., Huang, X.H., 2014a. Rare earth elements activate endocytosis in plant cells. Proc. Nat. Acad. Sci. U.S.A. 111, 12936-12941.

Wang, L., Wang, W., Zhou, Q., Huang, X., 2014b. Combined effects of lanthanum (III) chloride and acid rain on photosynthetic parameters in rice. Chemosphere 112, 355-361. Wen, K., Liang, C., Wang, L., Hu, G., Zhou, Q., 2011. Combined effects of lanthanumion and acid rain on growth, photosynthesis and chloroplast ultrastructure in soybean seedlings. Chemosphere 84, 601-608.

Wu, J., Wang, C., Mei, X., 2001. Stimulation of taxol production and excretion in Taxus spp cell cultures by rare earth chemical lanthanum. J. Biotechnology 85, 67-73.

Xia, B., Sun, Z., Wang, L., Zhou, Q., Huang, X., 2017. Analysis of the combined effects of lanthanum and acid rain, and their mechanisms, on nitrate reductase transcription in plants. Ecotox. Environ. Safe. 138, 170-178.

Xu, X., Zhu, W., Wang, Z., Witkamp, G. J., 2002. Distribution of rare earths and heavy metals in field-grown maize after application of rare earth-containing fertilizers, Sci. Total Environ. 293, 97-105.

Zeng, Q., Zhu, J.G., Cheng, H.L., Xie, Z.B., Chu, H.Y., 2006. Phytotoxicity of lanthanum in rice in haplic acrisols and cambisols. Ecotox. Environ. Safe. 64, 226-233.

Zhang, J., Zhang, T., Lu, Q., Cai, S., Chu, W., Qiu, H., Xu, T., Li, F., Xu, Q., 2015.

Oxidative effects, nutrients and metabolic changes in aquatic macrophyte, Elodea nuttallii, following exposure to lanthanum, Ecotox. Environ. Safe. 115, 159-165. 
278 Zhang, F., Cheng, M., Sun, Z., Wang, L., Zhou, Q., Huang, X., 2017. Combined acid rain and

279 lanthanum pollution and its potential ecological risk for nitrogen assimilation in soybean

280 seedling roots. Environ. Pollut. 231, 524-532.

281

282

283

284

285

286

287

288

289

290

291

292

293

294

295

296

297

298

299

300

301

302 
304 Fig 1. Hypothetical threshold, linear non-threshold (LNT), and hormetic dose-response 305 models. The maximum stimulatory response (MAX) in the hormetic model is commonly 306 below 200\%. The toxicological thresholds above which adverse effects appear in the 307 threshold and hormetic models are indicated by no-observed-effects-level (NOEL) and no308 observed-adverse-effects-level (NOAEL).

309

310 Fig 2. Typical examples of hormetic dose responses from published literature. When needed, 311 response data were estimated from figures of reviewed articles using image analysis software 312 (Adobe Photoshop CS4 Extended v.11, Adobe Systems Incorporated, CA, USA). 
Fig 1.
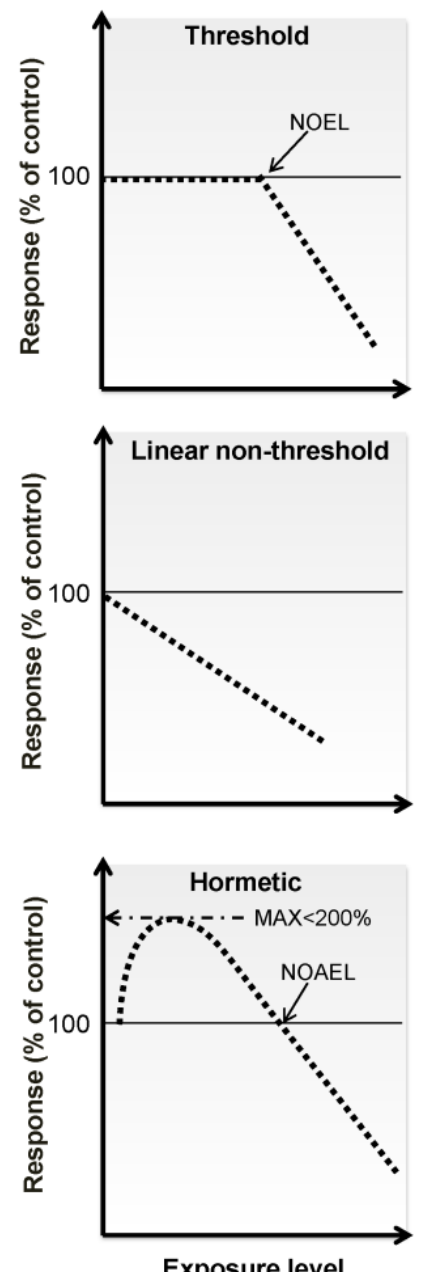
$332 \quad$ Fig 2.
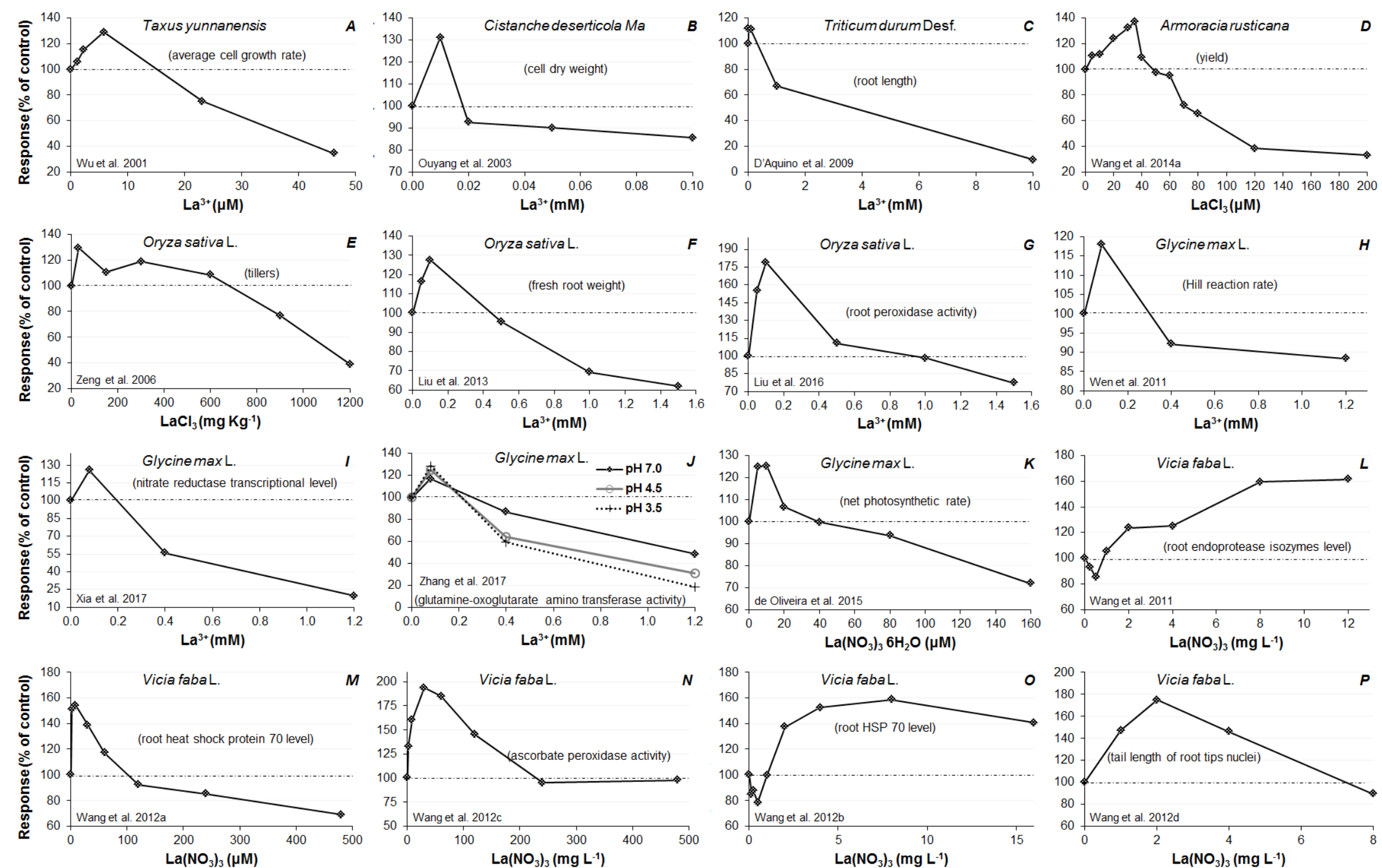
